\section{Request for an Opinion}

Correspondence

Franco Dellaglio

franco.dellaglio@univr.it

\section{The status of the species Lactobacillus rogosae Holdeman and Moore 1974. Request for an Opinion}

\author{
Giovanna E. Felis, Sandra Torriani and Franco Dellaglio \\ Dipartimento Scientifico e Tecnologico, Università degli Studi di Verona, 37134 Verona, Italy
}

\begin{abstract}
A brief history of the species Lactobacillus rogosae is presented. It was ascertained that the type strain and other existing strains are not available in any established culture collection; therefore, they cannot be included in any scientific study. This matter is referred to the Judicial Commission, asking for an Opinion on the status of the species.
\end{abstract}

The species Lactobacillus rogosae was described by Holdeman \& Moore (1974) on the basis of at least nine strains. Cells were rod-shaped, Gram-positive, catalasenegative, non-spore-forming and obligately anaerobic and produced lactic acid and acetic acid. The type strain ATCC $27753^{\mathrm{T}}$, corresponding to the original isolate VPI C $37-38^{\mathrm{T}}$, and several other strains were found to be motile and peritrichous, but non-motile strains were also included in the species. Fermentation ability was restricted to fructose, with variable reactions with cellobiose and lactose. Growth temperature was above $30^{\circ} \mathrm{C}$, but below $45^{\circ} \mathrm{C}$, with an optimum at $37^{\circ} \mathrm{C}$. Finally, a $\mathrm{G}+\mathrm{C}$ content of $59 \mathrm{~mol} \%$ was reported for one of the isolates. The isolation origin, human faeces, was indicated only for the type strain.

In 1980, L. rogosae was included in the Approved List of Bacterial Names (Skerman et al., 1980), but Kandler \& Weiss (1986) described L. rogosae among species not to be considered in the genus Lactobacillus: they reported that 'no strains which correspond to the original description are presently available' since they had received two strains from VPI that resembled propionibacteria more than they did lactobacilli. In their conclusion, they stated that 'more investigations are needed to clarify the taxonomic position of L. rogosae'. L. rogosae was not considered in the phylogenetic study performed by Stackebrandt \& Teuber (1988) nor in the subsequent analysis of the genus Lactobacillus and related genera by Collins et al. (1991).

In order to include the type strain of L. rogosae in a comparative study in progress in our laboratory on the species belonging to the genus Lactobacillus, the availability of the original type strain, VPI C $37-38^{\mathrm{T}}$, was checked in different culture collections [American Type Culture Collection (ATCC, http://www.atcc.org), Deutsche Sammlung von Mikroorganismen und Zellkulturen (DSMZ,

Published online ahead of print on 30 July 2004 as DOI 10.1099/ ijs.0.63099-0. http://www.dsmz.de), BCCM ${ }^{\mathrm{TM}} / \mathrm{LMG}$, Belgian Bacteria Collection (http://www.belspo.be/bccm), Japan Collection of Microorganisms (JCM, http://www.jcm.riken.go.jp/)] and with the original owner VPI, i.e. Anaerobe Culture Collection, Virginia Polytechnic Institute and State University, Blacksburg, VA, USA.

It was found that none of the aforementioned culture collections owns the strain, and that the Anaerobe Laboratory that housed the VPI collection no longer exists (John Hess, Virginia Polytechnic Institute and State University, personal communication). Part of the VPI collection was transferred to the ATCC (John Hess, personal communication), but, on its part, the ATCC does not posses strain VPI C $37-38^{\mathrm{T}}$ (ATCC, personal communication) nor ATCC $27753^{\mathrm{T}}$, indicated as corresponding to the original type strain in the description of Holdeman \& Moore (1974) and by Pot et al. (1994).

In accordance with Rule $18 \mathrm{~g}$ of the Bacteriological Code (Lapage et al., 1992), we are referring to the Judicial Commission the unavailability of strain VPI C $37-38^{\mathrm{T}}$ and, therefore, its unsuitability as the type strain of L. rogosae.

Rule 18c of the Bacteriological Code (Lapage et al., 1992) states that 'if a strain on which the original description was based cannot be found, a neotype strain may be proposed. Unfortunately, all the existing strains of L. rogosae are either unavailable for incomplete accession process in the ATCC (ATCC, personal communication) or not present in the other major culture collections.

Since, according to Rule 30 of the Bacteriological Code (Lapage et al., 1992), the name of a species is not validly published if a culture of a type strain is not readily available in at least one of the established culture collections, the status of the whole species $L$. rogosae is also referred to the Judicial Commission.

On the basis of the presented evidence, we suggest the 
rejection of the species name, at least until strains under accession process in the ATCC are available and confirmed as belonging to the genus Lactobacillus.

\section{References}

Collins, M. D., Rodrigues, U. M., Ash, C., Aguirre, M., Farrow, J. A. E., Martinez-Murcia, A., Phillips, B. A., Williams, A. M. \& Wallbanks, S. (1991). Phylogenetic analysis of the genus Lactobacillus and related lactic acid bacteria as determined by reverse transcriptase sequencing of $16 \mathrm{~S}$ rRNA. FEMS Microbiol Lett 77, 5-12.

Holdeman, L. V. \& Moore, W. E. C. (1974). New genus, Coprococcus, twelve new species, and emended descriptions of four previously described species of bacteria from human feces. Int J Syst Bacteriol 24, 260-277.
Kandler, O. \& Weiss, N. (1986). Regular, nonsporeforming Grampositive rods. In Bergey's Manual of Systematic Bacteriology, vol. 2, pp. 1208-1234. Edited by P. H. A. Sneath, N. S. Mair, M. E. Sharpe \& J. G. Holt. Baltimore: Williams \& Wilkins.

Lapage, S. P., Sneath, P. H. A., Lessel, E. F., Skerman, V. B. D., Seeliger, H. P. R. \& Clark, W. A. (editors) (1992). International Code of Nomenclature of Bacteria (1990 Revision). Bacteriological Code. Washington, DC: American Society for Microbiology.

Pot, B., Ludwig, W., Kersters, K. \& Schleifer, K.-H. (1994). Taxonomy of lactic acid bacteria. In Bacteriocins of Lactic Acid Bacteria: Microbiology, Genetics, and Applications, pp. 13-90. Edited by L. de Vuyst \& E. J. Vandamme. London: Blackie Academic \& Professional.

Skerman, V. B. D., McGowan, V. \& Sneath, P. H. A. (1980). Approved Lists of Bacterial Names. Int J Syst Bacteriol 30, 225-420.

Stackebrandt, E. \& Teuber, M. (1988). Molecular taxonomy and phylogenetic position of lactic acid bacteria. Biochimie 70, 317-324. 